\title{
The Association between N-terminal Pro-Brain Natriuretic Peptide Levels in the Umbilical Vein and Amniotic Fluid Volume Abnormalities
}

\section{Associação entre níveis de peptídeo natriurético pró- cerebral $\mathrm{N}$-terminal na veia umbilical e as anormalidades do volume de líquido amniótico}

\author{
Ali Ozgur Ersoy ${ }^{1} \quad$ Sibel Ozler $^{1} \quad$ Efser Oztas $^{1} \quad$ Ebru Ersoy $^{1} \quad$ Merve Ergin $^{2} \quad$ Salim Erkaya ${ }^{1} \quad$ Dilek Uygur $^{1}$ \\ ${ }^{1}$ Department of Obstetrics and Gynecology, Zekai Tahir Burak \\ Women's Health Care, Training and Research Hospital, Ankara, \\ Turkey \\ 2 Department of Biochemistry, Ataturk Education and Research \\ Address for correspondence Ali Ozgur Ersoy, MD, Department of \\ Obstetrics and Gynecology, Zekai Tahir Burak Women's Health Care, \\ Training and Research Hospital, Talatpasa Bulv. Hamamonu, 06230, \\ Altindag, Ankara, Turkey (e-mail: draliersoy@gmail.com).
} Hospital, Ankara, Turkey

Rev Bras Ginecol Obstet 2016;38:177-182.

\begin{abstract}
Purpose The amniotic fluid volume (AFV) is known as a predictor for the wellness of a fetus. We aimed to investigate whether $\mathrm{N}$-terminal pro-brain natriuretic peptide (NTproBNP) levels reflect AFV abnormalities in otherwise normal fetuses.

Methods We recruited 24 women with isolated oligohydramnios, 23 women with isolated polyhydramnios, and 36 women with normal AFV at a tertiary referral center. NT-proBNP levels in umbilical venous samples and the individual characteristics of the three groups were compared. One-way ANOVA and Kruskal-Wallis analysis of variance were used for multi-group comparisons of continuous variables. When a significant difference was detected, the Scheffe test was performed as a post-hoc analysis. Proportions were compared using the Chi-square $(\chi 2)$ test.

Results Maternal age, body mass indices, weight gained in pregnancy and NT-proBNP levels were similar among the three groups. Apgar scores at 1 and 5 minutes

\section{Keywords}

- amniotic fluid volume

- oligohydramnios

- polyhydramnios

- pregnancy

- renal function significantly correlated with NT-proBNP levels in all newborns (Spearman's $r=0.23$; $p=0.03$ and Spearman's $r=0.24 ; p=0.02$, respectively). The umbilical venous NTproBNP levels did not differ between newborns who needed mechanical ventilation and those who didn't ( $p=0.595)$.

Conclusions NT-proBNP is a biomolecule that may provide insights into the pathogenesis of fetal circulatory problems and subsequent renal failure. Further investigations are warranted.
\end{abstract}

received

November 11, 2015

accepted

January 7, 2016
DOI http://dx.doi.org/ 10.1055/s-0036-1583172. ISSN $0100-7203$.
Copyright $\odot 2016$ by Thieme Publicações License terms Ltda, Rio de Janeiro, Brazil

() (1) $\odot \circledast$ 


\section{Resumo}

\section{Palavras-chave \\ - volume do líquido amniótico \\ - oligoidrâmnios \\ - poli-hidrâmnios \\ - gravidez \\ - função renal}

Objetivo Investigar se os níveis de peptídeo natriurético pró-cerebral N-terminal (NTproBNP) refletem anormalidades no volume de líquido amniótico (VLA) em fetos normais.

Métodos Reunimos 24 mulheres com oligoidrâmnios isolados, 23 com poli-hidrâmnios isolados, e 36 com VLA normal em um centro de referência. Comparamos os níveis de NT-proBNP em amostras venosas umbilicais e características individuais em três grupos. Usamos análise de variância simples (One-way ANOVA) e a análise de variação Kruskal-Wallis para comparação de variáveis contínuas em múltiplos grupos. Quando identificada uma diferença significativa, o teste de Scheffe foi aplicado como uma análise post-hoc. Comparamos proporções usando o teste Qui-quadrado $(\chi 2)$.

Resultados Idade fértil, índice de massa corporal, ganho de peso na gestação e níveis de NT-proBNP foram similares nos três grupos. Apgar em 1 e 5 minutos correlacionaram significativamente com os níveis de NT-proBNP em todos os recém-nascidos (Spearman's $r=0,23 ; p=0,03$ e Spearman's $r=0,24 ; p=0,02$, respectivamente). Os níves de NT-proBNP venoso umbilical não se distinguiram entre os recém-nascidos que precisaram de ventilação mecânica e aqueles que não precisaram $(p=0,595)$. Conclusões NT-proBNP é um candidato biomolecular que pode contribuir na patogênese de problemas circulatórios fetais e subsequente insuficiência renal. São necessárias futuras investigações.

\section{Introduction}

Amniotic fluid volume (AFV) is influenced by various fetal organs, although the vast majority of amniotic fluid abnormalities is idiopathic. Amniotic fluid (AF) abnormalities are known to be associated with potential health problems in the fetus and the neonate. ${ }^{1}$ The $\mathrm{AF}$ is provided primarily by the fetal urine, and the major route of AF clearance occurs via fetal swallowing during the second part of pregnancy. ${ }^{2}$ Various mechanisms, such as placental insufficiency, fetal renal anomalies and fetal obstructive uropathies can cause oligohydramnios, while maternal diabetes mellitus, fetal polyuria, isoimmunization, and some congenital anomalies, such as esophageal atresia and duodenal atresia, can cause polyhydramnios. ${ }^{1}$ An ovine study demonstrated that the volume of AF swallowed by the fetus each day is a determinant of the AF volume, but the swallowing is not the major regulator of AF volume. ${ }^{3}$ In addition, another ovine study demonstrated that the fluid excreted from the fetal lungs failed to substantially contribute to the $\mathrm{AF}$ volume. ${ }^{4}$ Although various mechanisms have been suggested to contribute to the pathogenesis of isolated polyhydramnios and oligohydramnios, the exact mechanism that underlies these abnormalities remains to be determined.

Brain natriuretic peptide (BNP) is produced in cardiomyocytes and released into the circulation system in response to atrial and ventricular distention. The precursor of the probrain natriuretic peptide (ProBNP) performs different functions in the maintenance of cardiovascular, renal, and endocrine stability, and is cleaved into two molecules. One of these molecules is NT-proBNP, and the other molecule is BNP. ${ }^{5}$ BNP and NT-proBNP are released into the plasma in equimolar concentrations. ${ }^{6}$
Recent years have seen advances in assessing the renal effects of natriuretic peptides. It was showed that lower glomerular filtration rates occur in association with higher NT-proBNP levels. ${ }^{5,7}$ Also, the severity of cardiac dysfunction was shown to be associated with higher NT-proBNP levels. ${ }^{8}$ We investigated this topic in the context of the AFV, as the AFV is a clinically relevant variable in fetal health surveillance and a function of the fetal renal and circulatory systems. Thus, we aimed to investigate NT-proBNP levels in patients with and without AFV abnormalities.

\section{Methods}

Eighty-three singleton pregnant women who were past 28 weeks of gestation were included in this prospective casecontrol study. All of the included women visited the Zekai Tahir Burak Women's Health Care Training and Research Hospital in Ankara, where there is a tertiary referral center for perinatology, between August and December 2014. Recruitment was performed at the time of delivery. The study was approved by the Institutional Review Board (approval date/number: 28.04.2014/37), and the universal principles of the Helsinki Declaration were applied. ${ }^{9}$ All pregnant women in the study gave written informed consent to participate. Of the 83 included patients, 24 consecutive women were diagnosed with isolated oligohydramnios, 23 consecutive women were diagnosed with isolated polyhydramnios, and the remaining 36 women, who had normal AFV, were recruited as a control group with no matching. All of the recruited women were the ones who had been examined comprehensively with the use of ultrasonography for a fetal anomaly scan by a senior perinatologist between the gestational ages of 18 and 22 weeks. All participants attended regular 
antenatal visits. Women were excluded from the study for the following reasons: any form of coexisting fetal health abnormalities (previously diagnosed fetal cardiac, circulatory, renal or other anatomic abnormalities) detected via ultrasound; any detected Doppler waveform abnormalities in the uterine, umbilical and middle cerebral arteries (MCA); any sign of fetal anemia, intrauterine growth restriction (IUGR), or rupture of the membranes; any previously diagnosed maternal systemic disease (diabetes mellitus, cardiovascular, thyroidal, renal, or hepatic diseases, or any autoimmune disease); and the use of various drugs/substances that are likely to affect the circulatory system of the fetus (painkillers, alcohol, tobacco). All ultrasonographic evaluations were performed using a Voluson 730 Expert and a 3$5 \mathrm{MHz}$ convex transducer (GE Healthcare Systems, Kretztechnik, Zipf, Austria).

The diagnosis of oligohydramnios was made when the AF index was below $5 \mathrm{~cm}$. The diagnosis of polyhydramnios was made when the AF index was above $24 \mathrm{~cm} .{ }^{10}$ All diagnoses were confirmed by measuring the actual AFV during delivery.

Age (years), body mass index (BMI) $\left(\mathrm{kg} / \mathrm{m}^{2}\right)$, weight gain during pregnancy $(\mathrm{kg})$, obstetric history characteristics, hemoglobin value $(\mathrm{g} / \mathrm{dL})$, the length of postpartum hospitalization and total hospitalization (hours), and the AF index ( $\mathrm{mm}$ ) were recorded. BMI was calculated as the weight in kilograms divided by the height in square meters $\left(\mathrm{kg} / \mathrm{m}^{2}\right)$.

Umbilical venous blood samples $(3 \mathrm{~mL}$ ) were obtained from the newborn of each participant just after the expulsion phase of delivery and transferred to the laboratory within 20 minutes. Serum samples were separated by centrifugation at $5,000 \mathrm{rpm}(2,236 \mathrm{~g})$ for 10 minutes. The serum samples were stored at $-80^{\circ} \mathrm{C}$ until use. The serum NT-proBNP levels were determined using a commercially available enzyme-linked immunosorbent assay (ELISA) kit (USCNK, Wuhan, Hubei, PRC) and reported in $\mathrm{pg} / \mathrm{mL}$. The minimum detectable dose of this kit was $14 \mathrm{pg} / \mathrm{mL}$; the intra-assay and inter-assay variances were lower than $10 \%$ and $12 \%$ respectively.

The hemoglobin levels of the women were analyzed using an LH780 hematological analyzer (Beckman Coulter, Fullerton, CA, USA) within two hours of blood sampling and reported in $\mathrm{g} / \mathrm{dL}$.

The variables related to perinatal outcomes were birth weight (g), gestational week at delivery, Apgar scores at 1 and 5 minutes, the need for the neonatal intensive care unit (NICU), and the need for mechanical ventilation.

\section{Statistical Analysis}

The distributions of the variables were assessed using the Kolmogorov-Smirnov test or the Shapiro-Wilk test. Continuous variables were presented as the mean and standard deviation (SD) or the median (range). Categorical variables were presented as the number (percentage). One-way ANOVA and Kruskal-Wallis variance analysis were used for multi-group comparisons of continuous variables. When a significant difference was detected, the Scheffe test was performed as a post-hoc analysis. If the observed differences were significant, pair-wise comparisons were based on the Mann-Whitney U-test or the Bonferroni correction to determine which subgroups differed. Proportions were compared using the Chi-square $\left(\chi^{2}\right)$ test. Pearson's correlation coefficients were calculated for normally distributed continuous variables, and Spearman's rank correlation coefficients were calculated for non-normally distributed continuous variables. All analyses were conducted using SPSS software version 17.0 for Windows (SPSS, Chicago, IL, USA). In all analysis, two-tailed P-values of $<0.05$ were considered to be statistically significant.

\section{Results}

The three groups were similar in terms of age, BMI, gestational weight gain, maternal hemoglobin concentration, and the obstetric history characteristics of the patients, as shown in - Table 1. The AF indices of the patients were significantly different as a result of the categorization $(p<0.001)$. The serum NT-proBNP levels were also similar among the three groups (-Fig. 1, - Table 2 ).

The route of delivery and the indications for cesarean section (CS) did not differ among the three groups $\left(\chi^{2}=1.86 ; p=0.39\right.$ and $\left.\chi^{2}=3.02 ; p=0.93\right)$. In addition, the serum NT-proBNP levels were similar among patients who delivered by vaginal route and cesarean section $(p=0.77)$.

Both the birth weight and the gestational week at delivery differed significantly among the groups, and both of these parameters were consistent with the following ranking, with a descending trend among the three groups: Normal AFV > Polyhydramnios > Oligohydramnios (- Table 2). The Apgar scores at 1 and 5 minutes differed significantly among the groups, and both of these parameters were consistent with the following ranking, with a descending trend among the three groups: Normal AFV > Oligohydramnios > Polyhydramnios (-Table 2).

The need for mechanical ventilation occurred more frequently in the oligohydramnios group but did not differ significantly among the three groups $\left(\chi^{2}=4.92 ; p=0.08\right)$. The umbilical venous NT-proBNP levels exhibited no significant correlation with the amniotic indices of the patients ( $n=83$; Spearman's $r=0.2 ; p=0.07$ ). The umbilical venous NT-proBNP levels exhibited no correlation with the hemoglobin concentrations of the patients ( $n=83$; Spearman's $r=-0.142 ; p=0.199$ ).

No correlation was observed between the birth weights and NT-proBNP levels of the newborns in our study ( $n=83$; Spearman's $r=0.08 ; p=0.42$ ). Similarly, no correlation between gestational weeks at delivery and NT-proBNP levels was observed for all patients included in the study (Spearman's $r=0.05 ; p=0.63$ ) or for the patients with normal AFV (Spearman's $r=0.07 ; p=0.67$ ). The Apgar scores at 1 and 5 minutes were positively correlated with NT-proBNP levels in all newborns (Spearman's $r=0.237 ; p=0.031$ and Spearman's $r=0.24 ; p=0.029$ respectively). The umbilical venous NT-proBNP levels did not differ between newborns who needed mechanical ventilation and those who didn't $(p=0.595)$. 
Table 1 Comparison of demographic and clinical characteristics among the three groups

\begin{tabular}{|l|l|l|l|l|}
\hline Characteristics & $\begin{array}{l}\text { Oligohydramnios } \\
(\boldsymbol{n}=\mathbf{2 4})\end{array}$ & $\begin{array}{l}\text { Polyhydramnios } \\
(\boldsymbol{n}=\mathbf{2 3})\end{array}$ & $\begin{array}{l}\text { Normal Amniotic Volume } \\
(\boldsymbol{n}=\mathbf{3 6})\end{array}$ & $\boldsymbol{p}$ value \\
\hline Age (years) & $25.5 \pm 3.5$ & $25.3 \pm 3.8$ & $26.5 \pm 3.4$ & 0.6 \\
\hline BMI (kg/m $\left.{ }^{2}\right)$ & $28.5 \pm 1.6$ & $28.7 \pm 1.8$ & $28.8 \pm 1.8$ & 0.8 \\
\hline WG during pregnancy (kg) & $10.6 \pm 2.7$ & $11.0 \pm 3.1$ & $10.5 \pm 2.2$ & 0.7 \\
\hline Gravidity & $2(1-6)$ & $2(1-4)$ & $2(1-5)$ & 0.3 \\
\hline Parity & $1(0-4)$ & $1(0-3)$ & $1(0-4)$ & 0.7 \\
\hline Living child & $1(0-4)$ & $1(0-2)$ & $1(0-4)$ & 0.6 \\
\hline Abortus & $0(0-1)$ & $0(0-1)$ & $0(0-2)$ & 0.1 \\
\hline D\&C & $0(0-1)$ & $0(0-1)$ & $0(0-1)$ & 0.9 \\
\hline Amniotic index (mm) & $34.2 \pm 10.4$ & $257.48 \pm 7.0$ & $125.8 \pm 25.1$ & $<0.001^{*}$ \\
\hline Hemoglobin (g/dL) & $11.9 \pm 1.2$ & $11.90 \pm 1.01$ & $12.0 \pm 1.3$ & 0.9 \\
\hline Postpartum Stay (h) & $37.4 \pm 11.5$ & $37.78 \pm 12.1$ & $36.5 \pm 14.3$ & 0.9 \\
\hline Total Stay (h) & $55.8 \pm 15.9$ & $58.17 \pm 19.5$ & $52.08 \pm 16.8$ & 0.4 \\
\hline
\end{tabular}

Abbreviations: BMI, body mass index; D\&C, dilatation and curettage; g, grams; GW, gestational week; h, hours; MV, mechanical ventilation; WG, weight gain.

Note: The data are expressed as the mean \pm standard deviation or the median (range).

${ }^{*}$ indicates that the difference is significant at the 0.05 level.

\section{Discussion}

The similarity of the three groups with respect to demographic variables such as maternal age, BMI, gestational weight gain, obstetric history characteristics and maternal hemoglobin concentration increased the value of the comparisons. As NT-proBNP has previously been reported in association with renal and cardiac effects, in this study we hypothesized that proBNP may be associated with abnormal AFV. We suspected that the fluid volume in the fetal body and the volume load to the fetal heart may be associated with the AFV regardless of the source of $\mathrm{AF}$ (such as swallowing or intramembranous flow). We found no significant correlation between the AFV and the NT-proBNP levels of our participants, but we generated some interesting findings.

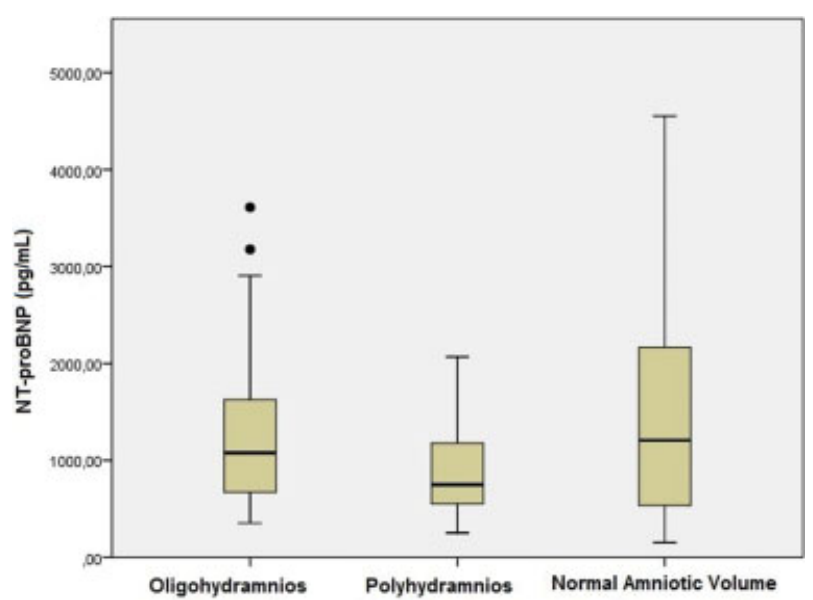

Fig. 1 The concentration of NT-proBNP (pg/mL, Y-axis) and changing levels of NT-proBNP in cord venous sera in the three groups (X-axis).
One of these findings was the observation that the Apgar scores at 1 and 5 minutes differed significantly among the groups; both of these parameters could be ranked as follows, with a descending trend among the groups: Normal AFV > Oligohydramnios $>$ Polyhydramnios. Although Apgar scores are widely recommended only for evaluating the need for neonatal resuscitation, it has been reported that low Apgar scores were associated with neonatal death and cerebral palsy. ${ }^{11}$ Another interesting finding was that the NT-proBNP levels exhibited a positive correlation with the Apgar scores at 1 and 5 minutes. In a study performed by Arad et al, it was reported that higher NT-proBNP levels were associated with low Apgar scores at 1 minute. ${ }^{12}$ That study included early preterm deliveries prior to 32 weeks of gestation, in contrast to our study. Compared with our study, higher umbilical venous NT-proBNP levels were reported in that study. Fetal blood NT-proBNP levels have been reported to decline with advancing gestational age in a low-risk population. ${ }^{13}$ Thus, the difference in NT-proBNP levels between the study performed by Arad et al and our study may have originated from the different gestational ages of the included patients. ${ }^{12}$

Renal failure and a low glomerular filtration rate are coincident with cardiac or circulatory failure. We performed our study based on these inferences. ${ }^{14}$ Recent years have seen advances in testing for the renal effects of natriuretic peptides. Anwaruddin et al ${ }^{15}$ demonstrated that lower glomerular filtration rates occurred in association with higher NT-proBNP levels. Similarly, two other studies demonstrated that both BNP and NT-proBNP could be elevated in patients with renal dysfunction. ${ }^{16,17}$ Various studies reported that NT-proBNP levels are associated with renal function and the glomerular filtration rate (GFR) to a greater degree than BNP levels; this difference occurs due to differences in the 
Table 2 Comparison of perinatal outcomes and umbilical venous N-terminal pro-brain natriuretic peptide levels among the three groups

\begin{tabular}{|l|l|l|l|l|}
\hline Characteristics & $\begin{array}{l}\text { Oligohydramnios } \\
(\boldsymbol{n}=\mathbf{2 4})\end{array}$ & $\begin{array}{l}\text { Polyhydramnios } \\
(\boldsymbol{n}=\mathbf{2 3})\end{array}$ & $\begin{array}{l}\text { Normal Amniotic Volume } \\
(\boldsymbol{n}=36)\end{array}$ & $\boldsymbol{p}$ value \\
\hline NT-Pro-BNP level (pg/mL) & $1298.4 \pm 900.6$ & $923.12 \pm 518.5$ & $1551.18 \pm 1148.9$ & 0.1 \\
\hline GW at delivery (weeks) & $37.0 \pm 2.5$ & $37.48 \pm 1.7$ & $39.19 \pm 1.3$ & $<0.001^{*}$ \\
\hline Birth weight (g) & $2856.6 \pm 738.4$ & $3314.35 \pm 428.8$ & $3450 \pm 400.5$ & $0.003^{*}$ \\
\hline Male newborn & $10(41.7 \%)$ & $11(47.8 \%)$ & $17(47.2 \%)$ & 0.8 \\
\hline Apgar1 & $7(4-9)$ & $7(3-9)$ & $7.5(6-9)$ & $0.02^{*}$ \\
\hline Apgar5 & $9(6-10)$ & $9(5-10)$ & $9.5(8-10)$ & $0.01^{*}$ \\
\hline Need for NICU [n (\% within group)] & $7(29.2 \%)$ & $4(17.4 \%)$ & $3(8.3 \%)$ & 0.1 \\
\hline MV [n (\% within group)] & $3(12.5 \%)$ & $1(4.3 \%)$ & 0 & 0.08 \\
\hline
\end{tabular}

Abbreviations: GW, gestational week; g, grams; Apgar1, Apgar score at 1 minute; Apgar5, Apgar score at 5 minutes; NICU, neonatal intensive care unit; MV, mechanical ventilation.

Note: The data are expressed as the number (\%), the median (range) or the mean \pm standard deviation.

* indicates that the difference is significant at the 0.05 level.

dependence of the clearance of these peptides on renal function. ${ }^{7,18,19}$

Sahin et $\mathrm{al}^{20}$ demonstrated that NT-proBNP has substantial efficacy for the identification of hemodynamic alterations. In addition, those authors stressed that this parameter might be useful for screening at-risk groups. Abnormal function and volume loading of the left ventricle ${ }^{21}$ and pressure load on the left ventricle may elevate the BNP level in newborns with congenital heart diseases. ${ }^{22}$ Circulating NT-proBNP levels in fetuses with cardiac defects have been reported as higher than in healthy fetuses. ${ }^{23}$ Thus, to ensure equality among groups, at the beginning of this study we excluded patients whose fetuses had congenital cardiac anomalies. In addition, we excluded patients who were diagnosed with IUGR because the levels of NT-proBNP can be altered by this condition. ${ }^{24}$

In a study by Merz et al, ${ }^{25}$ it was demonstrated that amniotic fluid levels of NT-proBNP are of fetal origin. They attributed it predominantly to fetal renal functions, but the exact origin in the fetal body remained to be elucidated. ${ }^{25}$

NT-proBNP levels were demonstrated to accurately reflect renal function when the cardiac and circulatory status are normal. ${ }^{5,26}$ It's been demonstrated that these levels were also superior to BNP, likely because the clearance of NTproBNP is more dependent on kidney function, while the clearance of BNP can be performed by other pathways. ${ }^{27}$

Due to the reported interference of NT-proBNP with anemia status, we excluded patients with any sign of fetal anemia (such as fetuses with abnormal MCA Doppler waveform or fetal hydrops). In addition, this diagnosis was confirmed at the neonatal evaluation. ${ }^{28}$ Nayer et $\mathrm{al}^{6}$ reported that the levels of natriuretic peptides were affected by the weight and age of the patient. However, we did not find any association between NT-proBNP levels and the weights of the newborns. Merz et $\mathrm{al}^{13}$ demonstrated that a decline in fetal blood NT-proBNP levels occurred with advancing gestational age in a low-risk population. In contrast, we found no correlation between NT-proBNP levels and gestational age among both the group of patients with normal AFV and the total samples of patients included in this study. Bakker et $\mathrm{al}^{29}$ and Bar-Oz et $\mathrm{al}^{30}$ reached the same inferences as our study related to the lack of correlations between NT-proBNP levels and the gestational age and mode of delivery.

The low number of cases represents a major limitation of our study. The small sample size was caused by the lack of isolated cases. Birth weight and gestational week at delivery were not homogeneous among the three groups, and the similarity of the NT-proBNP levels observed among the groups may have arisen from these variations. These factors represent another limitation of our study.

In conclusion, we found no association between the AFV abnormality and the cord NT-proBNP level, but we found that NT-proBNP levels correlated with the Apgar scores at 1 and 5 minutes. We propose that NT-proBNP may be a biomolecule with the potential to provide insights into the pathogenesis of circulatory problems and subsequent renal failure during the fetal period. Placental and amniotic fluid levels may be useful for determining the biological role of NT-proBNP in the future. Further investigations with larger population sizes are warranted to elucidate the molecular mechanisms associated with NT-proBNP and the effects of this peptide on fetal and neonatal well-being.

\section{Acknowledgments}

To Assistant Professor Dr. Mehmet Ersoy (Department of Computer Education and Instructional Technology, Osmangazi University, Eskisehir, Turkey) for assistance with the statistical analysis.

\section{References}

1 Guin G, Punekar S, Lele A, Khare S. A prospective clinical study of feto-maternal outcome in pregnancies with abnormal liquor volume. J Obstet Gynaecol India 2011;61(6):652-655 
2 Gizzo S, Noventa M, Vitagliano A, et al. An update on maternal hydration strategies for amniotic fluid improvement in isolated oligohydramnios and normohydramnios: evidence from a systematic review of literature and meta-analysis. PLoS ONE 2015; 10(12):e0144334

3 Brace RA, Anderson DF, Cheung CY. Fetal swallowing as a protective mechanism against oligohydramnios and polyhydramnios in late gestation sheep. Reprod Sci 2013;20(3):326-330

4 Robertson P, Faber JJ, Brace RA, et al. Responses of amniotic fluid volume and its four major flows to lung liquid diversion and amniotic infusion in the ovine fetus. Reprod Sci 2009;16(1):88-93

5 Schaub JA, Coca SG, Moledina DG, Gentry M, Testani JM, Parikh CR. Amino-terminal pro-B-type natriuretic peptide for diagnosis and prognosis in patients with renal dysfunction: a systematic review and meta-analysis. JACC Heart Fail 2015;3(12):977-989

6 Nayer J, Aggarwal P, Galwankar S. Utility of point-of-care testing of natriuretic peptides (brain natriuretic peptide and $\mathrm{N}$-terminal pro-brain natriuretic peptide) in the emergency department. Int J Crit Illn Inj Sci 2014;4(3):209-215

7 Gür M, Uçar H, Kuloğlu O, et al. Estimated glomerular filtration rate is associated with both arterial stiffness and $\mathrm{N}$-terminal probrain natriuretic peptide in newly diagnosed hypertensive patients. Clin Exp Hypertens 2014;36(6):374-379

8 Duan HY, Liu DM, Qian P, et al. Effect of atorvastatin on plasma NTproBNP and inflammatory cytokine expression in patients with heart failure. Genet Mol Res 2015;14(4):15739-15748

9 World Medical Association. World Medical Association Declaration of Helsinki: ethical principles for medical research involving human subjects. JAMA 2013;310(20):2191-2194

10 Oyelese Y. Placenta, umbilical cord and amniotic fluid: the not-lessimportant accessories. Clin Obstet Gynecol 2012;55(1):307-323

11 Jensen LV, Mathiasen R, Mølholm B, Greisen G. Low 5-min Apgar score in moderately preterm infants; association with subsequent death and cerebral palsy: a register based Danish national study. Acta Paediatr 2012;101(2):e80-e82

12 Arad I, Bar-Oz B, Ergaz Z, Nir A, Barak V. Interleukin-6 and Nterminal pro-brain natriuretic peptide cord blood levels in premature infants: correlations with perinatal variables. Isr Med Assoc J 2010;12(7):419-423

13 Merz WM, Kübler K, Albers E, Stoffel-Wagner B, Gembruch U. Reference values for N-terminal pro-B-type natriuretic peptide in fetal circulation between 20 and 34 weeks of gestation. Clin Biochem 2010;43(4-5):519-521

14 Curtis BM, Parfrey PS. Congestive heart failure in chronic kidney disease: disease-specific mechanisms of systolic and diastolic heart failure and management. Cardiol Clin 2005;23(3):275-284

15 Anwaruddin S, Lloyd-Jones DM, Baggish A, et al. Renal function, congestive heart failure, and amino-terminal pro-brain natriuretic peptide measurement: results from the ProBNP Investigation of Dyspnea in the Emergency Department (PRIDE) Study. J Am Coll Cardiol 2006;47(1):91-97

16 Mueller C, Laule-Kilian K, Scholer A, et al. B-type natriuretic peptide for acute dyspnea in patients with kidney disease: insights from a randomized comparison. Kidney Int 2005;67(1): $278-284$
17 Scheven L, de Jong PE, Hillege HL, et al; PREVEND study group. High-sensitive troponin $\mathrm{T}$ and $\mathrm{N}$-terminal pro-B type natriuretic peptide are associated with cardiovascular events despite the cross-sectional association with albuminuria and glomerular filtration rate. Eur Heart J 2012;33(18):2272-2281

18 Austin WJ, Bhalla V, Hernandez-Arce I, et al. Correlation and prognostic utility of B-type natriuretic peptide and its aminoterminal fragment in patients with chronic kidney disease. Am J Clin Pathol 2006;126(4):506-512

19 DeFilippi C, van Kimmenade RR, Pinto YM. Amino-terminal proB-type natriuretic peptide testing in renal disease. Am J Cardiol 2008;101(3A):82-88

20 Şahin M, Portakal O, Karagöz T, Hasçelik G, Özkutlu S. Diagnostic performance of BNP and NT-ProBNP measurements in children with heart failure based on congenital heart defects and cardiomyopathies. Clin Biochem 2010;43(16-17):1278-1281

21 Westerlind A, Wåhlander H, Lindstedt G, Lundberg PA, Holmgren D. Clinical signs of heart failure are associated with increased levels of natriuretic peptide types B and A in children with congenital heart defects or cardiomyopathy. Acta Paediatr 2004;93(3):340-345

22 Cowley CG, Bradley JD, Shaddy RE. B-type natriuretic peptide levels in congenital heart disease. Pediatr Cardiol 2004;25(4): 336-340

23 Merz WM, Kübler K, Albers E, Stoffel-Wagner B, Gembruch U. Nterminal pro-B-type natriuretic peptide in the circulation of fetuses with cardiac malformations. Clin Res Cardiol 2012; 101(2):73-79

24 Iacovidou N, Briana DD, Boutsikou M, et al. Perinatal changes of circulating N-terminal pro B-type natriuretic peptide (NTproBNP) in normal and intrauterine-growth-restricted pregnancies. Hypertens Pregnancy 2007;26(4):463-471

25 Merz WM, Leufgen C, Fimmers R, Stoffel-Wagner B, Gembruch U. Reference intervals for $\mathrm{N}$-terminal pro-B-type natriuretic peptide in amniotic fluid between 10 and 34 weeks of gestation. PLoS ONE 2014;9(12):e114416

26 Maisel A, Mueller C, Adams K Jr, et al. State of the art: using natriuretic peptide levels in clinical practice. Eur J Heart Fail 2008; 10(9):824-839

27 Vickery S, Price CP, John RI, et al. B-type natriuretic peptide (BNP) and amino-terminal proBNP in patients with CKD: relationship to renal function and left ventricular hypertrophy. Am J Kidney Dis 2005;46(4):610-620

28 Tongprasert F, Srisupundit K, Luewan S, Tongsong T. Comparison of cardiac troponin $\mathrm{T}$ and $\mathrm{N}$-terminal pro-B-type natriuretic peptide between fetuses with hemoglobin Bart's disease and nonanemic fetuses. Prenat Diagn 2014;34(9):864-869

29 Bakker J, Gies I, Slavenburg B, Bekers O, Delhaas T, van DieijenVisser M. Reference values for N-terminal pro-B-type natriuretic peptide in umbilical cord blood. Clin Chem 2004;50(12):2465

30 Bar-Oz B, Lev-Sagie A, Arad I, Salpeter L, Nir A. N-terminal pro-Btype natriuretic peptide concentrations in mothers just before delivery, in cord blood, and in newborns. Clin Chem 2005;51(5): 926-927 